\title{
Farmer's Knowledge, Attitude and Practice about Health hazards of Pesticides at EI - Hammam village.
}

\author{
Omima Mostafa Abad- Elzaher , Mohammed Hassan Qayed, Safaa Ahmed Kotb, \&Asmaa Ghreeb Mohamed
}

Community Health Nursing, Faculty of Nursing, Qena University.

Public Health and Community Medicine, Faculty of Medicine, Assuit University.

Community Health Nursing, Faculty of Nursing, Assuit University.

\begin{abstract}
:
Back ground: Pesticide use in most developing countries causing serious damages to the ecosystem and human health. Aim of the study: to assess knowledge, attitudes and practices of farmers towards hazards of mis use of pesticides.Subject and Method: A descriptive research design was used. The study was conducted at El-Hammam Village, Abnoub District. A systematic random sample technique was used for selecting the study homes. Data collection took about 4 months. Two tools were used in this study; the first was an interview questionnaire sheet. The second tool was a Likert-type rating scale that was used to assess farmers' attitude towards pesticides. Results: It was found that $31.5 \%$ of the study participants were aged (40- >50 years), and the majority of the studied participants $(90.2 \%)$ were married. In addition, $45.5 \%$ of the study participants were illiterate. Conclusion: More than half of the studied farmers had poor knowledge about pesticides use. The prevalence rate of poisoning cases represent less than fifth. While the most fatalities of cases were found among human. Recommendations: The programs of health education campaigns should be organized and directed for farmers to increase their awareness of pesticides usage, storage, hazards and safety use.
\end{abstract}

Key words: Farmers, Awareness, Pesticides, Health hazards, Knowledge, Attitudes and Practices.

\section{Introduction:}

Farming is a demanding occupation requiring individuals to carry out a variety of tasks. Farmers, farm workers, and farm family members may operate agricultural machinery, apply pesticides and fertilizers, build and repair equipment, and handle livestock which may put them at risk of injury and disease. (David, 2007)

Pesticide is a substance or mixture of substances intended for preventing, destroying, repelling, or lessening the damage caused by pests. It may be a chemical substance biological agent (virus or bacteria), antimicrobial, disinfectant or device. Many chemical pesticides are poisonous to humans. Pesticides are used both in farms and within our homes and gardens. (Govindarajan, 2006)

Pesticide-related health problems usually manifest as a series of symptoms depending on the severity of exposure. For instance, mild poisoning manifests in the form of malaise, vomiting, nausea, diarrhea, loose stools, sweating, abdominal pain and salivation. Moderate poisoning includes dyspnea, decreased muscular strength, bronchospasm, muscle fasciculation, tremor, and motor in coordination, bradycardia, and hypotension/hypertension. Severe manifestation could result in coma, respiratory paralysis, extreme hyper secretion, cyanosis, sustained hypotension, extreme muscle weakness, muscular paralysis and convulsion. (Jinky, 2007)
Health hazards of pesticides are a matter of global concern today. Pesticides are taken for granted in a framer's daily use, and their toxicity is frequently ignored. Careless handling and needless exposure can cause serious burns, poisonings, asphyxia, tissue damage, or even cancer, thus farmers need to be warned of and protected from the hazards associated with the use of pesticides. (Allender and Spradly, 2011)

The role of the occupational health nurse is broad and includes health care provider, manager/coordinator, educator/advisor, and case manager, depending on the type of work and the country in which the nurse practices. (Alleyne, 2009)

The World Health Organization (WHO) and the United Nations Environmental Programmed (UNEP) estimated that one to five million cases of pesticide poisoning occur among agricultural workers each year with about 20,000 fatalities. (Conway and Pretty, 2006)

Farm workers face a disproportionately high risk of exposure to pesticides due to their hand-labor work in agriculture. The families of farm workers can be exposed to pesticides through drift or secondary exposure when a worker brings pesticide residues home on clothing and transfers these residues to family members. (National Environmental Health Association, 2009)

There are no previously published studies regarding farmer's knowledge, attitude and practice about 
pesticides in El-Hammam Village, Abnoub District, Assiut Governorate. So the present study has been conducted in this area because there is no enough information about risky use of pesticides. Farmers' knowledge about proper handling and use of such dangerous and hazardous substances is poor because of illiteracy and poverty

Significant of the study:

According to WHO pesticide use causes 3.5 to 5 million acute cases of poisoning every year. Health and environmental hazards of pesticide occur due to lack of information, awareness and knowledge which are chief contributing factors of extensive overuse or misuse of hazardous pesticide and dangerous practices. (Forget, 2010)

\section{Aim of the study:}

To assess knowledge, attitude and practice of farmers towards health hazards of mis use of pesticides at El-Hammam Village.

\section{Research questions:}

Q.1-What is the personal data about farmers at ElHammam Village?

Q.2-What is the level of farmers' knowledge about pesticides and their adverse health effects at ElHammam Village?

Q.3- What are the attitudes of farmers at El-Hammam Village regarding pesticides' use?

Q.4- What are the practices of farmers at ElHammam Village in relation to pesticides' use?

\section{Subject and method:}

\section{Research design:}

A descriptive research design was used in this study

\section{Study Setting:}

This study was conducted at El- Hammam Village, which is one of Abnoub rural areas. It lies 4 kilometers to the South-East of Abnoub district. It has a total population of around 24, 711, about 3000 of them working in agricultural activities. As all rural areas with agricultural activities, farmers of $\mathrm{El}$ Hammam Village use pesticides to protect their crops from pests.

\section{Study subjects:}

All people whose land farming is their main work (either land owners or land renters) were eligible to be included in the study.

\section{Sample size calculations:}

The sample size of this study has been calculated through using the following equation:

$$
\mathrm{n}=\frac{\mathrm{Z}^{2} \mathrm{p} \times \mathrm{q}}{\mathrm{d}^{2}}
$$

$\mathrm{n}=$ the desired sample size.

$\mathrm{z}=$ the standard normal deviate, usually set 1.96 (or more simply at 2.0).
$\mathrm{P}=$ the proportion in the target population estimate to have a particular characteristics. If there is no reasonable estimate, then use $50 \%(0.05)$

$\mathrm{q}=(100 \%-\mathrm{p})$

For example, if the proportion of a target population with a certain characteristics is 0.05 , the $\mathrm{z}$ statistics is 1.96 (2.0), and we desired accuracy at 0.05 , then the sample size is

$$
\mathrm{n}=\frac{\mathrm{Z}^{2} \mathrm{px}}{\mathrm{d}^{2}}=\frac{2^{2} \times 5 \times 5 \times 100 \times 100}{5 \times 5 \times 10 \times 10}=400
$$

based on prevalence rate of knowledge of pesticides use $(50 \%)$ and at a confidence level (95\%) Level of significant is less than (0.05)

this equation is applicable when the study community is 10000 or more

\section{Sampling technique:}

According to the local authority unit of El-Hammam village, divided it into four geographical sectors and present numbering in every house in the sector, Systematic random sample technique was used for selecting the study homes by dividing the number of total households of the village (5600) on the calculated sample size (400), so the width of the systematic random sample was as follow: 5600

$$
\longrightarrow=14
$$

400

\section{Study tools:}

to tools were conducted in this study:

I- The first tool was an interview questionnaire sheet regarding pesticides health hazards. This tool was divided into three parts:

Part (1): It was designed to assess personal data about the study sample including (age, marital status, education, family type and farmer's field if owned or rented and .......etc).

Part (2): It was designed to assess farmer's knowledge about pesticides health hazards including (route and harmful effects of pesticides on human health, alternative methods of pesticides, uses and benefits of pesticides and .......etc).

According to this system depended on the study of (Mo'awad, 2006), a scoring system was designed for the assessment of knowledge (13 questions). A score one was given for each correct answer and a score zero was given for an incorrect answer. The scores of each item were summed and then converted into a percent score. Poor knowledge: score of less than $50 \%$, Satisfactory knowledge: if score is $50-70 \%$ and Good knowledge: if score is more than $70 \%$.

Part (3): It was designed to assess farmer's knowledge about practice of using pesticides including (storage, preparation, disposal of its containers, and .......etc). 
Regarding total scoring for Farmer's practice. It consists of (20 questions), a score one was given for each correct answer and a score zero was given for an incorrect answer. The scores of each item are summed and then converted into a percent score. Poor practice: score of less than $50 \%$, satisfactory practice: if score is $50-70 \%$ and Good practice: if score is more than $70 \%$. (Mo'awad, 2006)

II - The second tool was a Likert-type rating scale which was used to assess farmer's attitudes towards pesticides including (Pesticides use is mandatory to farmers, Pesticides may adversely affect health at long run, Compliance with instructions is very important in the use of pesticides and .......etc). (Likerat scle, 2010)

Regarding total scoring for attitude, it consists of (21 items). Each question is scored using a three point Likert scale, ranging from (agree, not sure and disagree). Items were scored (2, 1 and 0$)$ respectively in English form and translate into Arabic using standard translating measure. (Likert scale, 2010). It was calculated by summing-up and then converted into a percent score. Farmer's attitude were considered positive attitude if the score was more than $60 \%$ and negative attitude if the score less than $60 \%$.

\section{Validation of the study:}

The modified tool of the study was distributed to a group of experts two of them were in the fields of community health nursing; one of them was in the field of statistics, who recommended face and content validity of all items. All recommended modifications were performed and the tool was tested through the pilot study.

\section{Methodology:}

I-Administrative phase:

An approval letter was taken from the dean of the Faculty of Nursing, Assiut University and then from the Director of Abnoub Agriculture Association to conduct the study at EL- Hammam village.After full explanation about the aim of the study.

\section{II-Pilot study:}

A pilot study was carried out before starting data collection on 20 farmers, who were excluded from the sample because there was a certain modification in the questionnaire. The aim of pilot study was to test the clarity of the tool, and to estimate the time required to fill out the form.

\section{III- Data collection phase: \\ Ethical considerations:}

The researcher explained the purpose and nature of the study to every study participant. An informed consent to participate in the study was taken orally from every participant and they assured that the information obtained will be confidential and used only for the scientific purposes of the study.

Field work:

Data were collected during the period from the first of February until the end of May 2013. It consumed about 4 months through home visit technique. The researcher had conducted structured interviews with the study participants at their own homes at suitable times to them (either morning or afternoon). The average time taken to complete each interview ranged from 35- 45 minutes according to the home circumstances or participants respond.

Statistical analysis:

The collected data were tabulated, scored, and analyzed by computer using the "Statistical Package for the Social Sciences" (SPSS) version 16. Chi square and correlations were used to compare difference in the distribution of frequencies between different groups. 
Results:

Table (1): Personal characteristics of the study participants $(n=400)$

\begin{tabular}{|c|c|c|}
\hline Variables & No. $(n=400)$ & $\%$ \\
\hline \multicolumn{3}{|l|}{ Age: (Years) } \\
\hline$<40$ & 117 & 29.2 \\
\hline $40-<50$ & 126 & 31.5 \\
\hline $50-<60$ & 77 & 19.2 \\
\hline$\geq 60$ & 80 & 20.0 \\
\hline Mean \pm SD & \multicolumn{2}{|c|}{$46.49 \pm 13.64$} \\
\hline (Range) & \multicolumn{2}{|c|}{$(17-86)$} \\
\hline \multicolumn{3}{|l|}{ Level of education: } \\
\hline Illiterate & 182 & 45.5 \\
\hline Read \& write & 56 & 14.0 \\
\hline Primary & 26 & 6.5 \\
\hline Preparatory & 25 & 6.2 \\
\hline Secondary & 84 & 21.0 \\
\hline University & 27 & 6.8 \\
\hline \multicolumn{3}{|l|}{ Marital status: } \\
\hline Single & 32 & 8.0 \\
\hline Married & 361 & 90.2 \\
\hline Divorced & 3 & 0.8 \\
\hline Widow & 4 & 1.0 \\
\hline \multicolumn{3}{|l|}{ Type of family: } \\
\hline Nuclear & 324 & 81.0 \\
\hline Extended & 76 & 19.0 \\
\hline \multicolumn{3}{|l|}{ Family size: } \\
\hline$<5$ & 86 & 21.5 \\
\hline $5-7$ & 215 & 53.8 \\
\hline$>7$ & 99 & 24.8 \\
\hline Mean \pm SD & \multicolumn{2}{|c|}{$6.20 \pm 2.35$} \\
\hline (Range) & \multicolumn{2}{|c|}{$(2-15)$} \\
\hline \multicolumn{3}{|l|}{ Number of rooms per household: } \\
\hline $1-2$ & 114 & 28.5 \\
\hline $3-4$ & 202 & 50.5 \\
\hline 5 or more & 84 & 21.0 \\
\hline Mean \pm SD & \multicolumn{2}{|c|}{$3.60 \pm 1.81$} \\
\hline (Range) & \multicolumn{2}{|c|}{$(1-12)$} \\
\hline
\end{tabular}


Table (2): Distribution of the study participant's knowledge about pesticides $(n=400)$

\begin{tabular}{|c|c|c|}
\hline knowledge & No. $(n=400)$ & $\%$ \\
\hline \multicolumn{3}{|c|}{ The agronomist visits the farm/ field regularly: } \\
\hline Yes & 207 & 51.8 \\
\hline No & 193 & 48.2 \\
\hline \multicolumn{3}{|c|}{ The agronomist gives instructions on pesticide use: } \\
\hline Yes & 149 & 37.2 \\
\hline No & 251 & 62.8 \\
\hline \multicolumn{3}{|c|}{ Cautions used while dealing with pesticides : } \\
\hline Yes & 253 & 63.2 \\
\hline No & 147 & 36.8 \\
\hline \multicolumn{3}{|c|}{ Experience of dealing properly with pesticides : } \\
\hline Yes & 69 & 46.9 \\
\hline No & 78 & 53.1 \\
\hline \multicolumn{3}{|l|}{ Sources of experience: * } \\
\hline Agricultural instructor & 6 & 8.7 \\
\hline Work Practice & 49 & 71.0 \\
\hline Other family members & 14 & 20.3 \\
\hline \multicolumn{3}{|c|}{ Following the instructions labeled on the container label: } \\
\hline Yes & 280 & 70.0 \\
\hline No & 120 & 30.0 \\
\hline \multicolumn{3}{|c|}{ Reasons for not following the instructions: } \\
\hline I can't read or write & 36 & 30.0 \\
\hline I don't care & 27 & 22.5 \\
\hline Both & 57 & 47.5 \\
\hline
\end{tabular}

There is more than one answer

Table (3): Experiencing poisoning events by the study participants $(n=400)$

\begin{tabular}{|c|c|c|}
\hline Variables & No. $(n=400)$ & $\%$ \\
\hline \multicolumn{3}{|c|}{ Farmers / their family members/ their properties experienced poisoning events: } \\
\hline Yes & 60 & 15.0 \\
\hline No & 340 & 85.0 \\
\hline \multicolumn{3}{|l|}{ Times of experiencing poisoning: } \\
\hline Once & 39 & 65.0 \\
\hline Twice & 19 & 31.7 \\
\hline Thrice & 2 & 3.3 \\
\hline \multicolumn{3}{|l|}{ Place of poisoning: } \\
\hline Farm & 43 & 71.7 \\
\hline Home & 17 & 28.3 \\
\hline \multicolumn{3}{|l|}{ Who was poisoned: } \\
\hline Human & 27 & 45.0 \\
\hline Animals & 21 & 35.0 \\
\hline Birds & 12 & 20.0 \\
\hline
\end{tabular}


Table (4): Attitudes of the study participants toward pesticide use ( $n=400)$

\begin{tabular}{|c|c|c|c|c|c|c|}
\hline \multirow{2}{*}{ Attitudes } & \multicolumn{2}{|c|}{ Agree } & \multicolumn{2}{|c|}{ Not sure } & \multicolumn{2}{|c|}{ Disagree } \\
\hline & No. & $\%$ & No. & $\%$ & No. & $\%$ \\
\hline Pesticide use is mandatory to farmers & 368 & 92.0 & 3 & 0.8 & 29 & 7.2 \\
\hline $\begin{array}{l}\text { Knowing the expiry date of the pesticides is an } \\
\text { important thing }\end{array}$ & 359 & 89.8 & 19 & 4.8 & 22 & 5.5 \\
\hline $\begin{array}{l}\text { Consulting a pesticide expert is an important thing to } \\
\text { the farmer }\end{array}$ & 325 & 81.2 & 25 & 6.2 & 50 & 12.5 \\
\hline $\begin{array}{l}\text { Using a spraying machine is better than manual } \\
\text { spraying }\end{array}$ & 387 & 96.8 & 9 & 2.2 & 4 & 1.0 \\
\hline Pesticides may adversely affect health in the long run & 129 & 32.2 & 81 & 20.2 & 190 & 47.5 \\
\hline $\begin{array}{l}\text { The body forms immunity against pesticides when } \\
\text { exposed to them for long periods }\end{array}$ & 136 & 34.0 & 110 & 27.5 & 154 & 38.5 \\
\hline $\begin{array}{l}\text { The pesticides of high concentration are more } \\
\text { effective than diluted ones }\end{array}$ & 196 & 49.0 & 84 & 21.0 & 120 & 30.0 \\
\hline $\begin{array}{l}\text { The use of mixed pesticides is more effective than the } \\
\text { single ones }\end{array}$ & 136 & 34.0 & 83 & 20.8 & 181 & 45.2 \\
\hline $\begin{array}{l}\text { Compliance with use instructions is very important in } \\
\text { dealing with pesticides }\end{array}$ & 311 & 77.8 & 54 & 13.5 & 35 & 8.8 \\
\hline Pesticides must be handled with caution & 338 & 84.5 & 25 & 6.2 & 37 & 9.2 \\
\hline $\begin{array}{l}\text { Empty pesticide containers can be used as home } \\
\text { utensils }\end{array}$ & 54 & 13.5 & 2 & 0.5 & 344 & 86.0 \\
\hline $\begin{array}{l}\text { Poisoned persons could be treated on site, and there is } \\
\text { no need to seek medical service }\end{array}$ & 48 & 12.0 & 5 & 1.2 & 347 & 86.8 \\
\hline Poisoned animals must be treated & 325 & 81.2 & 0 & 0.0 & 75 & 18.8 \\
\hline $\begin{array}{l}\text { When preparing or spraying pesticides, we must } \\
\text { avoid touching them directly }\end{array}$ & 194 & 48.5 & 4 & 1.0 & 202 & 50.5 \\
\hline $\begin{array}{l}\text { When preparing pesticides, wives/ kids can help in the } \\
\text { process }\end{array}$ & 166 & 41.5 & 4 & 1.0 & 230 & 57.5 \\
\hline $\begin{array}{l}\text { When preparing or spraying pesticides it is necessary } \\
\text { to cover nose/mouth with a mask, paper tissue, light } \\
\text { towel, or piece of cloth }\end{array}$ & 228 & 57.0 & 9 & 2.2 & 163 & 40.8 \\
\hline $\begin{array}{l}\text { One must change his clothes after preparing or } \\
\text { spraying pesticides }\end{array}$ & 272 & 68.0 & 122 & 30.5 & 6 & 1.5 \\
\hline $\begin{array}{l}\text { When getting sick during preparing or spraying } \\
\text { pesticides, one must stop and seek medical care }\end{array}$ & 339 & 84.8 & 58 & 14.5 & 3 & 0.8 \\
\hline $\begin{array}{l}\text { One must wash hands properly after preparing or } \\
\text { spraying pesticides }\end{array}$ & 377 & 94.2 & 23 & 5.8 & 0 & 0.0 \\
\hline $\begin{array}{l}\text { One must take a shower after preparing or spraying } \\
\text { pesticides }\end{array}$ & 273 & 68.2 & 114 & 28.5 & 13 & 3.2 \\
\hline $\begin{array}{l}\text { During pesticide handling, one can eat, drink or } \\
\text { smoke }\end{array}$ & 146 & 36.5 & 5 & 1.2 & 249 & 62.2 \\
\hline
\end{tabular}

Table (5): Distribution of the study participants regarding pesticide storage, preparation and disposal of their containers $(n=400)$

\begin{tabular}{|c|c|c|}
\hline $\begin{array}{r}\text { Variables } \\
\end{array}$ & No. $(n=400)$ & $\%$ \\
\hline \multicolumn{3}{|l|}{ Places of storing pesticides : } \\
\hline Household & 158 & 39.5 \\
\hline Farm & 242 & 60.5 \\
\hline \multicolumn{3}{|l|}{ Places of storing pesticides at home: } \\
\hline Anywhere & 28 & 17.7 \\
\hline
\end{tabular}




\begin{tabular}{|c|c|c|}
\hline Special place & 130 & 82.3 \\
\hline Variables & No. $(n=400)$ & $\%$ \\
\hline \multicolumn{3}{|l|}{ Places of preparing pesticides: } \\
\hline At home & 10 & 2.5 \\
\hline At farm & 390 & 97.5 \\
\hline \multicolumn{3}{|l|}{ Preparing pesticides in a special container: } \\
\hline Yes & 297 & 74.2 \\
\hline No & 103 & 25.8 \\
\hline \multicolumn{3}{|c|}{ Keeping empty pesticide containers inside homes or disposing of them: } \\
\hline Yes & 50 & 12.5 \\
\hline No & 350 & 87.5 \\
\hline \multicolumn{3}{|l|}{ Reasons of keeping empty pesticide containers : } \\
\hline Home use (water and food storage) & 37 & 74.0 \\
\hline For other types of pesticide storage & 13 & 26.0 \\
\hline \multicolumn{3}{|c|}{ Methods of disposing empty pesticides containers : * } \\
\hline Dumping garbage in or next to the street & 100 & 28.6 \\
\hline Throwing it on the farm & 116 & 33.1 \\
\hline Burying or incinerating it & 204 & 58.3 \\
\hline In the canal & 121 & 34.6 \\
\hline
\end{tabular}

There is more than one answer

Table (6): Relationship between study participants knowledge and their experience, agronomist visit, and occurrence of poisoning events $(n=400)$

\begin{tabular}{|c|c|c|c|c|c|c|c|}
\hline \multirow{2}{*}{$\begin{array}{l}\text { Variables } \\
\text { The agronomist visits the farm/ } \\
\text { field regularly: }\end{array}$} & \multicolumn{6}{|c|}{ Knowledge } & \multirow[b]{2}{*}{ P-value } \\
\hline & \multicolumn{2}{|c|}{$\begin{array}{c}\text { Poor } \\
(n=208)\end{array}$} & \multicolumn{2}{|c|}{$\begin{array}{r}\text { Satisfactory } \\
(\mathrm{n}=147)\end{array}$} & \multicolumn{2}{|c|}{$\begin{array}{c}\text { Good } \\
(n=45)\end{array}$} & \\
\hline Yes & 107 & 51.7 & 75 & 36.2 & 25 & 12.1 & \multirow[t]{2}{*}{0.861} \\
\hline No & 101 & 52.3 & 72 & 37.3 & 20 & 10.4 & \\
\hline \multicolumn{7}{|l|}{$\begin{array}{l}\text { Experience of dealing properly } \\
\text { with pesticides : }\end{array}$} & \multirow{3}{*}{$0.006^{*}$} \\
\hline Yes & 123 & 48.6 & 92 & 36.4 & 38 & 15.0 & \\
\hline No & 85 & 57.8 & 55 & 37.4 & 7 & 4.8 & \\
\hline \multicolumn{7}{|l|}{$\begin{array}{l}\text { Farmers, their family } \\
\text { members and his properties } \\
\text { experienced to pesticides } \\
\text { poisoning : }\end{array}$} & \multirow{3}{*}{$0.012 *$} \\
\hline Yes & 22 & 36.7 & 26 & 43.3 & 12 & 20.0 & \\
\hline No & 186 & 54.7 & 121 & 35.6 & 33 & 9.7 & \\
\hline
\end{tabular}

There is statis. Sign .def

Fig. (1): Knowledge of the study participants about the routes through which pesticides invade the human body at El-Hamamm Village, Abnoub District, Assiut Governorate, 2013. 


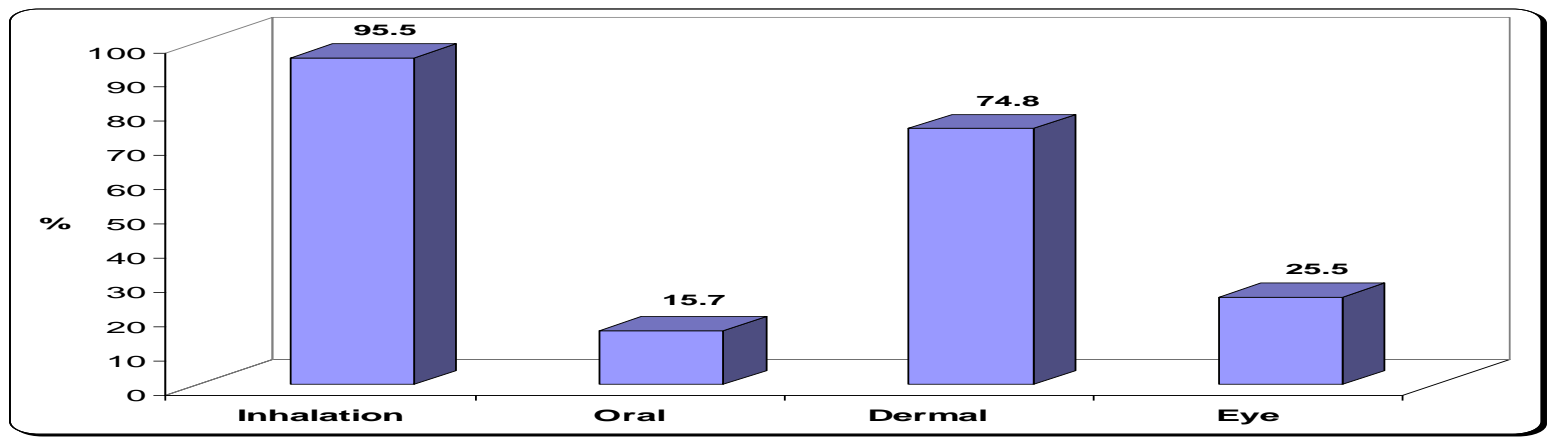

Fig. (2): Total score of participants' practice of pesticide use at El- Hamamm Village, Abnoub District, Assiut Governorate, 2013

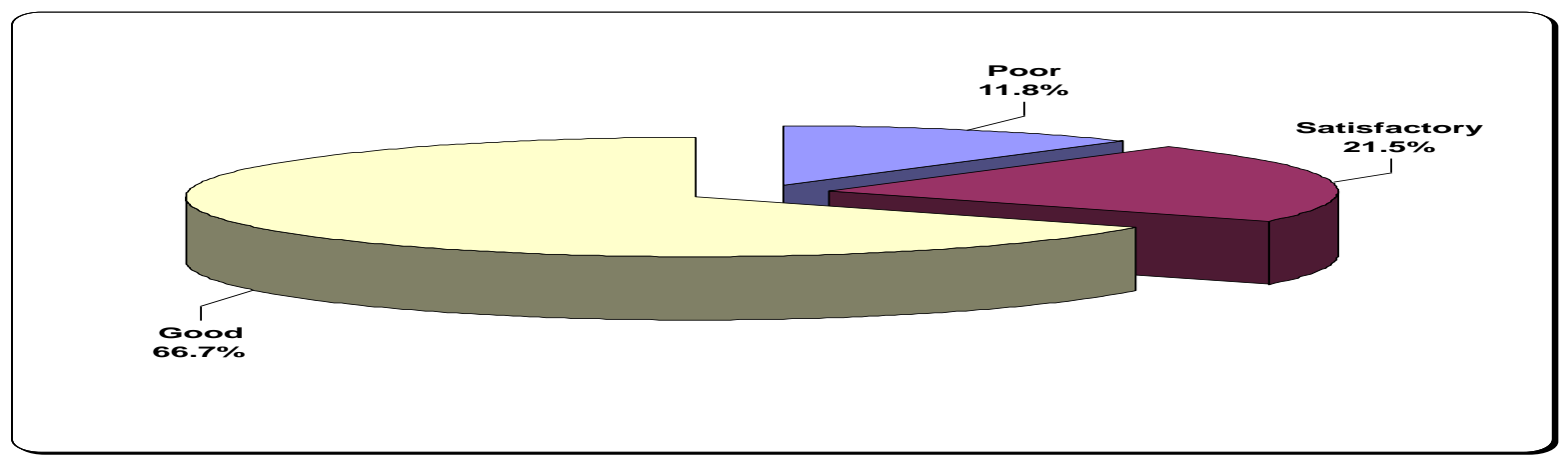

Table (1) shows some- personal characteristics of the study participants. It reveals that $31.5 \%$ of the studied farmers were in the age group 40- >50 years, and $20.0 \%$ were in the age group $\geq 60$ years.

Regarding marital status, the majority of the studied participants (90.2\%) were married. In addition, results show that $45.5 \%$ of the studied farmers were illiterate, and about $6.8 \%$ had university education.

Regarding the crowding index, it was revealed that more than two thirds of the participants $(69.5 \%)$ had a crowding index from 2- 3 persons, and $81.0 \%$ come from nuclear families. .

Table (2) reveals that distribution of the study participant's knowledge about properly and cautiously dealing with pesticides. As observed from the table, half of the studied participants $(51.8 \%)$ reported that the agronomist visits their farm regularly, and $37.2 \%$ mentioned that the agronomist gives instruction on pesticide use. Also, it was estimated that $63.2 \%$ of them reported that they dealt cautiously with these pesticides. In addition, $46.9 \%$ tried to gained experience to deal properly with pesticides. The study results show that $71.0 \%$ gained experience from work practice, and about $8.7 \%$ gained experience from agricultural instructors. In addition, $70.0 \%$ of the participants reported that they followed the instructions on the container label. As regards the reasons for not following the instructions on the container label, it was noticed that $47.5 \%$ of them stated that they do not follow these instructions because they don't read and write or because they don't care for following instructions on the containers $(30 \%, 22.5 \%$, respectively).

Table (3) illustrates the experiencing poisoning events by the study participants. It was observed that prevalence rate of poisoning represent less than fifth $(15.0 \%)$ distributed to poisoning for human, animals and birds. The most fatalities of cases were found among human resulting from pesticides spraying, while $65.0 \%$ of them stated that exposure to pesticides poisoning was happen once time. The results show that $45.0 \%$ of the studied participants mentioned that humans were poisoned from pesticides, while $20.0 \%$ reported that birds were poisoned from pesticides and $71.1 \%$ of the studied farmers stated that poisoning cases happened on the farm.

Table (4) reveals the studied farmer's attitude towards pesticide use. It indicates that the majority $(92.0 \%)$ of the studied farmers agreed that pesticide use is mandatory to the farmers. The findings reveal that $96.8 \%$ of the studied sample agreed that using a spraying machine is better than manual spraying.

Also $86.8 \%$ of the studied participants disagreed that poisoned persons could be treated on site, and there is no need to seek medical service. In addition, 94.2\% of studied farmers agreed that one must wash hands properly after preparing or spraying pesticides, 
whereas more than half $(57.5 \%)$ disagreed that when preparing pesticides, wives/ kids could help in the process. The table also shows that more than two thirds of the studied farmers $(84.5 \%)$ agreed that pesticides must be handled with caution.

Table (5) shows the distribution of the study participants regarding pesticide storage, preparation and disposal of their containers. It was observed that $60.5 \%$ of the studied farmers stored pesticides on the farm, while $82.3 \%$ stored pesticides in a special place at home. As regards the places of preparing pesticides, it was revealed that the majority of the participants $(97.5 \%)$ prepared pesticides on the farm. Also, $74.2 \%$ prepared them in special containers. Also the table shows that $74.0 \%$ of the participants kept empty pesticide containers for home use (water and food storage), whereas $87.5 \%$ of the studied farmers disposed of empty containers of pesticides, $58.3 \%$ disposed of them by burying or incinerating them, and $28.6 \%$ disposed of them by dumping garbage in or next to the street.

Table (6) shows the relationship between study participant's knowledge and their experience, agronomist visit and occurrence of poisoning events.

It was observed that that there is a statistically significant difference between farmer's knowledge with level of education, experience of dealing properly with pesticides and Farmers, their family members and his properties experienced to pesticides poisoning.

$\mathrm{P}=(0.000,0.006$ and 0.012$)$ respectively.

Fig (1): The majority of the studied farmers $(95.5 \%)$ reported that inhalation was the most common route through which pesticides can invade the human body, followed by dermal route $74.8 \%$ and $15.7 \%$ stated that the oral route was the least common route through which pesticides enter the human body.

Fig (2): Show the total practice scores of farmers regarding pesticide use, it was revealed that two thirds $(66.8 \%)$ of the studied farmers had good practice towards pesticide use, $21.5 \%$ of them had satisfactory practice, and about $11.8 \%$ had poor one.

\section{Discussion}

Environmental pollution represent one of the major problems facing the world today is environmental pollution. One of the sources of pollution in the area of agriculture is excessive use of pesticides. (Elmore, 2010)

The present study aimed to assess knowledge, attitudes and practices of farmers towards health hazards of mis use of pesticide at El-Hammam Village, Abnoub District, Assiut Governorate.

The findings of the present study showed that the age range of the studied farmer's age was (17-86) years.
These findings agreed with that reported by (Amr, 2010), and (Mo'awad, 2006) who found that the age of the studied farmers ranged between (17-81) and (15-79) years respectively. On other hand, these findings disagreed with that reported by (Mekonnen and Agonafir, 2010) and (Gaberand and Hassan, 2012) who found that the age of the studied farmers ranged between (16-50) and (15-62) years respectively.

The study results showed that as the age increase the knowledge of the studied

farmers decrease there was no relation between farmer's age and their knowledge, attitude and practice regarding pesticides use $(\mathrm{P}=0.085),(\mathrm{P}=$ 0 . 612) and $(P=0.44)$ respectively. This result agreed with (Mo'awad, 2006) who found that there was no relation between farmer's age and level of knowledge, attitude and practice regarding pesticides use $(P=0.060),(P=0.459)$ and $(P=0.091)$ respectively.

Concerning farmer's educational level, the findings indicated that around half (45.5) of the study participants were illiterate. It shows as the level of education increase the knowledge of the studied farmers increase. A significant relation was observed between farmer's knowledge, attitude and practice and their education. Similar findings were that reported by (Gaberand and Hassan, 2012) and another study reported by (Farahat et al, 2012) who found that there was a significant relation between farmer's knowledge, attitude and practice and their education. In contrast this results disagreed with the findings of the (Thaseen, 2007 ), (Yassin et al, 2012) and another study reported by (Tadesse and Asferachew, 2008), who found that there was no significant relation between farmer's knowledge, attitude and practice and their education.

As regards marital status, the present study showed that the majority of the study participants were married. This findings was in the same line with (Yassin et al, 2012), (Banjo et al, 2010) and (Mo'awad, 2006) who found that majority of the study participants were married. In contrast, these results disagreed with (Mekonnen and Agonafir, 2009) and (Gaberand and Hassan, 2012) who found that more than half of the studies were single.

As regards crowding index between the studied farmers, the findings of the present study showed that more than two third of the studied farmers had a crowding index from 2- 3 persons. This findings confronted with that reported by (Mo'awad, 2006) conducted a study in Cairo University who found that two third of the studied farmers had a crowding index $<2$ persons.

The present study revealed that there was no significant relation between farmer's knowledge and 
agronomist visit to the farm regularly. Also this study revealed that there was a significant relation between farmer's attitude and practice and agronomist visit to the farm regularly. Similar findings were that reported by (Thaseen, 2007) and (Mo'awad, 2006) who found that there was significant relation between farmer's attitude and practice and an agronomist visit to farm regularly. In relation to agronomist instructions, the results showed that more than one third of the participants stated that an agronomist give instructions on pesticides use.This results agreed with the results of (Thaseen, 2007) and (Mo'awad, 2006) who found that (36.0\%) and (34.0\%) respectively of the participants stated that an agronomist give instructions on pesticides use and this may be related to hazards of pesticides and farmers are exposed to increasing amount of pesticides without following precautions about labeling pesticides.

Regarding the experience of dealing properly with pesticides, the study findings showed that there was a significant relation between farmer's knowledge, attitude and practice and experience of dealing properly with pesticides, in addition this result revealed that work practice was the most common reported source of this experience. And this is because continuous work with family members to learn how dealing properly with pesticides

Concerning farmers following pesticides instruction printed on the containers, the findings revealed that more than two third of the studied farmer. This results was similar with the findings reported by (Tadesse and Asferachew, 2008), (Mo'awad, 2006) and (Juliana et al, 2012), who found that (69.0\%), $(73.0 \%)$ and $(77.0 \%)$ respectively of the studied farmers following the instructions printed on the container of agricultural pesticides. While this results disagreed with (Indira, 2009) and (Mo'awad, 2006), who found that more than two third of the studied farmers not following the instructions printed on the container of agricultural pesticides. Also this findings disagreed with (Atreya, 2007 ) who found that more than half of the studied sample not following the instructions printed on the container of agricultural pesticides. This may be related to hazards of pesticides and farmers are exposed to increasing amount of pesticides without following precautions about labeling pesticides.

As regards experiencing poisoning events by the study participants. It was observed that prevalence rate of poisoning represent less than fifth distributed to poisoning for human, animals and birds. The most fatalities of cases were found among human. This may be related to not have knowledge about hazards of pesticides and how to use it properly under supervision of an agronomist. As regards human poisoning resulting from pesticides. The findings revealed that more than two third of those who reported poisoning stated that place of poisoning was taken place at home. As regards to symptoms of poisoning majority of them reported that vomiting was the most common symptoms of poisoning, while more than half of the participants reported fever, in relation to the cause of poisoning, it was noticed that more than half of those who reported that inhaling polluted air was cause of poisoning. As regarding to action taken in case of poisoning, it was revealed that majority of those who reported human poisoning referral to health unit or hospital in case of poisoning resulting from pesticides.

As regards the attitudes of the studied farmer's towards pesticides used, the results of the present study illustrated that more than one third of the studied sample reported that bodies of farmers formulates immunity against pesticides when used for long periods. This finding was in the same line with (Thaseen, 2007), who reported that bodies of farmers formulate immunity against pesticides. The results in disagreement with the findings that reported by (Mo'awad, 2006), who found that more than two third of the studied farmers stated that their body didn't developed immunity against pesticides.

The findings showed that half of the studied sample preferred to increase the pesticides concentration to ensure the effectiveness of it. This findings was in the same line with the findings reported by (Mo'awad, 2006) who found that $(53.0 \%)$ of the studied sample preferred to use more than the recommended pesticide concentration to assure its effect. Also, these findings agreed with that reported by (Thaseen, 2007) who showed that a total $(80 \%)$ of the studied sample used recommended concentration of pesticides; only (10\%) did not use specific concentrations.

As regarding pesticides important for the farmers, but it must be treated with caution The findings of the current study was in the line with the findings reported by (Mo'awad, 2006) who found that majority of the studied farmers stated that pesticides important for them, but it must be treated with caution.

Concerning places of storing pesticides, the results of the present study revealed that two third of the studied farmers stored pesticides at farm. In relation storing pesticides at home majority of the participants stored it at special place at home this may be related to pesticides consider sources of pollution and farmers know hazards of pesticides and its effect on their children. This findings agreed with that reported by (Yassin et al, 2012), who found that more than two third of the studied farmers stored pesticides at farm. In contrast, these results disagreed with that 
reported by (Tadesse and Asferachew , 2008 ), who found that more than half of the participants stored pesticides in special places, while stored at home one third of them stored it at any were at home and about $(5.7 \%)$ stored it in kitchen at home .

As regards keeping pesticide bottles or disposal of them, results showed that the majority of the participants disposing empty containers of pesticides. The findings showed that more than half of the studied farmers disposing it by buried or incinerated it and this may be related to farmer's knowledge about hazard of pesticides and its effect on health and environment. This findings was in the same line with the findings that reported by (Yassin et al, 2012) and (Mo'awad, 2006), who found that around the half $(44.0 \%)$ and $(45.0 \%)$ respectively of the studied sample burying pesticides empty containers. On the other hand, these findings disagreed with that reported by (Gaberand and Hassan, 2012)., who found that only $(4 \%)$ of the studied farmers dispose pesticide container by burying it. The findings revealed that $(28.6 \%)$ of the studied sample disposing empty pesticides containers by dumping garbage in or next to the street. This results was in the same line (Mo'awad, 2006) who found that more than one third $(37.0 \%)$ of the studied sample thrown pesticides empty containers at the street. In contrast, this results disagreed with that reported by (Thaseen, 2007) who found that $(12 \%)$ of the studied sample thrown pesticides empty containers at the street.

Concerning reasons of keeping empty pesticides containers the results showed that more than two third of the participants keeping it for home use (water and food storage). This may be related to farmer's attitude that pesticides empty containers can be used in home utensils. The finding of the current study was in the same line with (Tadesse and Asferachew, 2008) and (Gaberand and Hassan, 2012) who found that around the half of the studied farmers used pesticides empty containers for water and/or food storage. On the other hand. The findings confronted with that reported by

( Indira , 2009 ), (Yassin et al, 2012) , (Juliana et al, 2012) and (Mo'awad, 2006) who reported that majority of the studied farmers not used pesticides empty containers for water and/or food storage.

\section{Conclusions:}

Based on the results of the present study, it was concluded that as the age increase the knowledge of the studied farmers decrease. With no statistically significant difference between age and farmers knowledge. As the level of education increase the knowledge of the studied farmers increase. Also, the result revealed that there was a statistically significant difference between farmer's knowledge with level of education. On the other hand the prevalence rate of poisoning represent less than fifth distributed to poisoning for human, animals and birds. The most fatalities of cases were found among human. It was concluded that more than half of the studied farmers had poor knowledge regarding pesticides use, while the majority of them had positive attitude regarding pesticides use.

\section{Recommendations:}

Based on the previous findings of the present study, the following recommendations are suggested:

1- Health education programs should be organized for farmers to stress the importance of safety guidelines when preparing or spraying pesticides.

2- Mass media and announcements such as (T.V., Radio) play an important role in conveying health information to the public and farmers.

3- Conduct regular training courses by agronomist visit to farmers regarding

Pesticides use, hazards to health and importance of personal protective equipment.

\section{References}

1. Allender, J., Spradly, B., and Karen, S., (2011): Community Health Nursing, Concepts and Practice, $5^{\text {th }}$ edition. Lippincott Company, New York, p.p; 343- 354.

2. Alleyne, J., (2009): Occupational Health Nurses' Roles, Credentials, and Continuing Education in Ontario, Canada. AAOHN Journal, Vol .57, Issue (9), pp; 389-395.

3. Amr, S., (2010): Disorders in Egyptian Pesticide Formulators, Department of Occupational Medicine and Department of Psychiatry, Cairo University, Egypt , pp; 30 -63.

4. Atreya, K., (2007): Pesticide use knowledge and practices: gender differences in Kathmandu, Nepal. Environ Res. 2007; 104(2):305-311.Doi: 10.1016/j.envres.2007.01.001.

5. Banjo, A., Aina, I., and Rije, S., (2010): Farmers' Knowledge and Perception towards Herbicides and Pesticides Usage African Journal of Basic \& Applied Sciences, Department of Plant Sciences, and Applied Zoology, AgoIwoye, Nigeria PP; 188-194.

6. Conway, G., and Pretty, N., (2006): Agriculture and pollution of pesticides. London: Earthscan Publications Ltd, Oxford Journals Medicine Journal of Public Health Vol. 28, Issue (1), Pp. 43-48.

7. David, S., (2007): Acute Pesticide Poisonings in Canada is available through the National Library of Canada. Vol. 5, Issue. (1) pp. 90- 120. 
8. El more, R ., and Arcury, T., (2010): Pesticide exposure beliefs among Lation Farm workers In North Calornia's Christmas Tree Industry, American Journal of industrial medicine, vol. 40, No.(2), pp:153-160.

9. Farahat, A., Abdelrasoul, F., and Amr, E., (2012): Neuro behavioral effects among workers occupationally exposed to organ phosphorous pesticides, Occup Environ Med doi: 10.1136/oem.60.4.279 PP. 279-286. Located at:http://oem.bmj.com/content/60/4/279.full.html

10. Forget, G., (2010): "Pesticide and the third world", Journal of Toxicology and Environmental Health, Vol. 5, (32), Pg. 11-13.

11. Gaberand, S., and Hassan, S., (2012): Health Education and Behavioral Sciences, High Institute of Public Health, 2Vector Control and pesticides risk. Journal of Occupational Medicine and Toxicology, Alexandria university, Pp.1/3/ Located at: http://www.occupmed.com/content/1/3/7.

12. Govindarajan, M., (2006): Pesticides in Environmental Science \& Technology; on line at: http://pubs.acs.org/subscribe/journals/esthagw.

13. Indira, D., (2009): Health Risk Perceptions, Awareness and Handling Behavior of Pesticides by Farm Workers, Agricultural Economics Research Review, Vol. 3, (22), pp: 263-268.

14. Jinky, L., and Del Prado, J., (2007): National Institutes of Health, University of the Philippines, Manila, Philippines. Journal of Occupational Medicine and Toxicology, Vol .11, doi: 10, pp. /1/2/9. The electronic version of this article is the complete one and can be found online at: http://www.occupmed.com/content/1/2/9.

15. Juliana, O., and Torres, A., (2012): Knowledge, Attitudes, Practices and Biomonitoring of Farmers and Residents Exposed to Pesticides in Brazil, Int. J. Environ. Res. Public Health 2012, 9, 3051-3068; doi: 10.3390/ijerph9093051. Located at: www.mdpi.com/journal/ijerph.

16. Likerat scle (2010): instrument that design for an attitude, Neag School of Education University of Connecticut located at:

17. http://www.gifted.uconn.edu/siegle/research/i nstrument \% 20reliability \%20and\%20validity/ likert.html .

18. Mekonnen, Y., and Agonafir, T., (2010): Pesticide sprayers' knowledge, attitude and practice of pesticide use on agricultural farms of Ethiopia. Occup Med Vol .52 (6) Pp. 311-315. Doi: $10.1093 /$ occmed/52.6.311.
19. Mo'awad, E., (2006): Farmers' Awareness About Health Hazards Of Agricultural Pesticides Use At Shubramant Village, Giza Governorate. Faculty of Nursing, Cairo University, Egypt, pp. $1-27$.

20. National Environmental Health Association, (NEHA), (2009): for farmers, High risk exposure of pesticides, Pesticides Action Net Work Europe located at: www.epa.gov/.

21. Tadesse, A., and Asferachew, A., (2008): An assessment of the pesticide use, practice and hazards in the Ethiopian Rift Valley. Ministry of agriculture and rural development, Crop Protection Department; p.p 1-61.

22. Thassen, M., (2007): The exposure of Farmers and their families to pesticides in an agricultural community, Faculty of Graduate Studies, at anNajah National University, Nablus, Palestine. Vol .5 (1) Pp. : 170-183.

23. Yassin M., Abu Mourad, J., and Safi, M., (2012): Knowledge, attitude, practice, and toxicity symptoms associated with pesticide use among farm workers in the Gaza Strip. Occupational and Environmental Medicine, pp. 387-394. 